\title{
The influencing factors and hierarchical relationships of offshore wind power industry in China
}

\author{
Yan $\mathrm{Xu}^{1} \cdot$ Kun $\mathrm{Yang}^{1} \cdot$ Guohao Zhao $^{1}$ \\ Received: 7 January 2021 / Accepted: 30 April 2021 / Published online: 19 May 2021 \\ (C) The Author(s), under exclusive licence to Springer-Verlag GmbH Germany, part of Springer Nature 2021
}

\begin{abstract}
As a new and cost-effective renewable energy power generation technology, offshore wind power is getting more and more attention. The development of offshore wind power industry is affected by policy-making, technology management, resources and environment, market supply and demand, and the relationship among the influencing factors is complex. This paper analyzes the factors that affect offshore wind power industry from a unique and comprehensive perspective. Fourteen factors are selected and interpretative structural model (ISM) is established to study the relationship between the influencing factors of offshore wind power industry. The results show that 14 influencing factors can be divided into five levels: the first level is the surface factors, including the economic incentive policy, operation mechanism, industrial chain, energy market mechanism, investment, and financing mechanism; the second and third levels are the intermediate factors, including generation cost, operation management, and offshore wind power technology; the fourth and fifth levels are deep-seated factors, including development planning and grid price, site selection, R\&D investment, environmental protection policy, and offshore wind power supply. Deep-seated factors have a direct impact on the intermediate factors, the intermediate factors have an important impact on the surface factors, and the surface factors directly affect the development of offshore wind power industry. The influence of the 14 factors selected in this paper on offshore wind power industry is from bottom to top, from deep to shallow.
\end{abstract}

Keywords Offshore wind power $\cdot$ China $\cdot$ Influencing factor $\cdot$ Interpretative structural model $\cdot$ Policy review

\section{Introduction}

On December 12, 2020, in the climate ambition summit, President Xi Jinping announced that by 2030, the $\mathrm{CO}_{2}$ emissions from China's gross domestic product will drop by more than $65 \%$ compared with 2005 . The proportion of non-fossil energy to primary energy consumption will reach $25 \%$, and the total installed capacity of wind power and solar power will reach $1200 \mathrm{GW}$. The declaration further improves the bottomline standard of $\mathrm{CO}_{2}$ emission reduction target and clearly puts forward the target of installed capacity of wind power and solar power for the first time (New China Net 2020).

Responsible Editor: Roula Inglesi-Lotz

Yan Xu

xwwyfy@sina.com

1 School of Management Science and Engineering, Shanxi University of Finance and Economics, No 696, Wucheng Road,

Taiyuan 030006, Shanxi, China
China's commitment to achieve carbon neutrality by 2060 and increase the national contribution to $\mathrm{CO}_{2}$ emission reduction will play a positive role in strengthening the domestic determination of low-carbon transformation and the confidence of global climate governance, but it also faces huge challenges. In recent years, China's wind power development has made great achievements, especially the offshore wind power. In 2020, the new installed capacity of wind power in China reached 71.67 million kilowatts, including 68.61 million kilowatts for onshore wind power and 3.06 million kilowatts for offshore wind power (NEA 2021). Offshore wind power is set to grow globally to $228 \mathrm{GW}$ by 2023 and potentially to $1000 \mathrm{GW}$ by 2050 (International Renewable Energy Agency 2019). The increasingly prominent position of offshore wind power in renewable energy makes in-depth analysis of offshore wind power industry necessary. However, a drawback of wind as an energy source lies in its high variability (Kisvari et al. 2020), especially for offshore wind power (Bains et al. 2020). It is urgent to study the relevant factors affecting offshore wind power industry. Therefore, this paper studies the factors influencing the development of offshore 
wind power industry and the relationship between them, aiming to figure out the mechanism of these factors on offshore wind power industry and provide meaningful suggestions for the development of offshore wind power industry and promote the development of offshore wind power in China and the world.

The research perspectives affecting China's offshore wind power industry mainly involve resources, technology, market, policy, etc., but most of the perspectives are relatively single, and there is no in-depth decomposition of each perspective. So, there is a lack of analysis on the interaction between the influencing factors and the influence degree of each factor on the development of offshore wind power industry. This paper intends to use the ISM model to analyze the structure and hierarchy of the influencing factors of China's offshore wind power industry and explore the surface, intermediate, and deep factors which affect the offshore wind power industry.

The contributions of this paper are as follows: Firstly, it proposes a factor set influencing the development of offshore wind power industry from the dimensions of policy, technology, resources, and market and describes the characteristics of each segmentation factor, so as to clarify the correlation between each factor. Secondly, this paper analyzes the structure and hierarchy of the factors affecting the offshore wind power industry with the ISM model and explores the action path of each factor and analyzes the influence degree of each factor. Thirdly, based on the influence degree of each factor, this paper puts forward policy recommendations to promote the sound and rapid development of China's offshore wind power industry.

The rest of the article consists of six sections. The "Literature review" Section is the literature review, which mainly introduces some factors affecting the offshore wind power industry. The "Development status of offshore wind power" section introduces the development status of offshore wind power in the world and China and the relevant policies of offshore wind power in China. The "Methodology" section is methodology, which describes the modeling steps of the interpretative structural model in detail. The "The influencing factors of offshore wind power industry in China based on ISM model" section shows how to apply ISM to the research of the influencing factors of China's offshore wind power industry. The "Results and discussions" section is the result analysis of the model operation and discussions. The "Conclusions" section is the conclusions and policy implications based on the "Results and discussions" section.

\section{Nomenclature}

$\begin{array}{ll}A \text { Abbreviations } & \\ a_{i j} & \text { Adjacency matrix } \\ & \text { Effect value of } S_{i} \text { on } S_{j}\end{array}$

\begin{tabular}{ll} 
CDM & Clean development mechanism \\
COVID-19 & Corona Virus Disease 2019 \\
CWEA & China Wind Energy Association \\
GIS & Geographical Information Systems \\
GW & Gigawatt \\
GWEC & Global Wind Energy Council \\
$I$ & Identity matrix \\
ISM & Interpretative structural model \\
LCOE & Levelized cost of energy \\
$M$ & Reachability matrix \\
MCDM & Multi-criteria decision-making \\
MW & Megawatt \\
NDRC & National Development and Reform Commission \\
NEA & National Energy Administration \\
$P$ & Reachable set \\
$Q$ & Antecedent set \\
R\&D & Research and development \\
$S$ & The system factor set \\
$S_{i}$ & The $i$ th influencing factor in $S$ \\
$S_{j}$ & The jth influencing factor in $S$ \\
TWh & Terawatt hour \\
VAT & Value-added Tax \\
yuan/kWh & Yuan per kilowatt hour \\
\hline &
\end{tabular}

\section{Literature review}

Around the globe, government and legislative authorities at the local, regional, national, and international levels are highly concerned about the environmental impacts and risk factors that influence the energy paradigm (Nazir et al. 2020b). In the past two decades, with global energy, resources, and environmental problems becoming more and more prominent, especially global climate change, wind energy has stood up as a cost-effective source of energy. It is endorsed as having the emission-free ability, green, and is also subsidies by state support and credit benefits for taxes (Nazir et al. 2020c). What's more, it has become one of the fastest developing renewable energy in the world with the joint efforts of all countries (Guo et al. 2019). Wind energy stands out in the process of energy transformation because of its abundant reserves, clean and efficient advantages. Wind power is divided into onshore wind power and offshore wind power. Onshore wind power appeared earlier and its technology is relatively mature. Compared with onshore wind power, offshore wind power has the advantages of abundant wind energy resources, wind farm close to the energy load center, wide sea surface available area, and no land occupation. Ocean captures and stores huge amounts of energy, which could satisfy five times of world energy demand (Chen et al. 2018). The development of offshore wind power is an effective guarantee for China to 
realize the national energy structure adjustment. Therefore, the development and utilization of offshore wind power have been paid more and more attention. However, there are some problems in the development of offshore wind power, such as lack of technical strength, high generation cost, and lack of reasonable planning. In recent years, offshore wind power technology has made new breakthroughs. A decreasing trend in the cost of initial capital investment and the levelized cost of energy (LCOE) for offshore wind-power generation developments is projected to continue (O'Kelly 2019). In 2020, many countries around the world set "green energy transformation" as the focus of future economic development, resulting in a sudden increase in the number of offshore wind power projects under construction and to be built ( $\mathrm{Li} 2021)$. With the rapid development of global offshore wind power industry, the installed capacity is advancing by leaps and bounds, and the single unit capacity is also growing. The Corona Virus Disease 2019 (COVID-19) that has spread across the world has had a concussion on the energy industry: The construction schedule is postponed; the investment environment of the recession market is affected; in 2020, the electricity demand in some areas is expected to drop by $10 \%$. However, the development cycle of offshore wind power is long. To a large extent, it will not be affected by the short-term impact of the epidemic on the industrial chain like onshore wind power (Sun 2020). Therefore, offshore wind power is bound to play an important role in the future world energy structure.

China has become the global leader in wind power, its wind power development has greatly promoted the growth rate of global wind power, and it has become an indispensable force in global wind power development (Zhang et al. 2020). China has more than $18,000 \mathrm{~km}$ of continental coastline. In the offshore area within the 5-25 m water depth line, the installed capacity at $50 \mathrm{~m}$ above sea level is about $200 \mathrm{GW}$, and that above $70 \mathrm{~m}$ is about $500 \mathrm{GW}$ (Min et al. 2016). And Yang et al. (2017) have proved that the southeast region of China is particularly rich in offshore wind energy resources. China's offshore wind power potential is huge.

By combing the relevant literatures on the development of offshore wind power, it can be concluded that scholars study the factors influencing the development process of offshore wind power industry through the following aspects: First, policy-making. The development of offshore wind power will be affected by many policies, such as land use regulation, energy and environmental policy, economic incentive policy, and on grid price policy (Tu 2019; Liu et al. 2015). In particular, renewable energy policies also have an impact on the development of offshore wind power (Papiez et al. 2019). The promulgation of relevant policies will also have an impact on the technical innovation, operation and maintenance cost, and installed capacity of offshore wind power and then affect the development process of offshore wind power (Reichardt and Rogge 2015; Nguyen and Chou 2019; Cao 2018).
Although China has promulgated a series of policies to promote the development of offshore wind power industry and achieved certain results, it is not difficult to find that there are still some problems in China's industrial policies, such as unclear planning, low administrative efficiency, imperfect competitive allocation system construction, and insufficient financial support (Zhang 2019). Second, technical management. The high cost of technology research and development, high investment risk, and high energy price are the main reasons for the development difficulties of offshore wind power. Among them, the performance of wind turbines plays a key role in the breakthrough of offshore wind power technology (Tahir et al. 2020). What's more, the wind turbine with higher rated power produced higher energy output (Allouhi et al. 2017). In the field of offshore wind power and, in contrast to more developed countries, China still has a problem with both a weak technical support system and underdeveloped technologies (Zhang et al. 2018). There are few "highly cited" patents in China's offshore wind power industry, and the patent value is not high. The length of the patent reference chain is generally short, the inheritance of main technology flow is poor, the key technology path is monotonous, and the technical breakthrough is difficult (Zheng 2017). Third, resources and environment. First of all, considering the development cost, operation revenue forecast, wake effect, and other factors, the selection of offshore wind farm sites is a very complex problem (Wu et al. 2019; Cranmer et al. 2017). Tercan et al. (2020) provided a solution to the problem of offshore wind power location. It combined multi-criteria decision-making (MCDM) methods and geographical information systems (GIS) and was implemented in Cyclades (Greece) and in the sea area of the İzmir region (Turkey). MCDM methods and satellite technology for identifying suitable areas of wind power plants have become increasingly popular in site selection decision-making (Shao et al. 2020; Nezhad et al. 2020). Then, a precise assessment of wind resources is considered of paramount significance for the construction of offshore wind farms (Murthy and Rahi 2017; Guo et al. 2019). Ranthodsang et al. (2020) presented an offshore wind resource assessment and offshore wind power feasibility analysis on the western coast of Thailand. Accurate and reliable wind speed forecasting is also vital in power system scheduling and management (Peng et al. 2020). And high-quality wind data is essential for the whole wind energy assessment process (Zhao et al. 2019). China has a lot of potential offshore wind energy resources to be developed. Under the high-cost scenario forecast, it can provide $1148.3 \mathrm{TWh}$ of energy in a cost-competitive way, and under the low-cost scenario forecast, it can provide 6383.4TWh of energy, which is equivalent to $36 \%$ to $200 \%$ of the total coastal energy demand after 2020 (Sherman et al. 2020). Fourth, market supply and demand. With an increase in cooperation for wind farm development, the development became more international and with more frequent alliances 
(Dedecca et al. 2016). Offshore wind power project has a large amount of investment, and the demand for funds is relatively concentrated. The funds are mainly solved through internal financing and external financing (Zhang et al. 2015). The financing cost of offshore wind power investment can be reduced by broadening direct financing channels, improving private financing mechanism, introducing insurance policies to encourage offshore wind power enterprises, and establishing effective international reinsurance channels (Zhang and Huang 2018). At present, China's offshore wind power is in the stage of high-speed development, and the offshore wind power market has broad space and promising prospects (Xu et al. 2019). Facing the fierce market competition, China's offshore wind power should take "innovation" as the core and "cost reduction" as the goal, so as to better adapt to the current development of offshore wind power (Ji et al. 2019).

China is the world leader in wind energy, producing more than a third of the world's capacity (Nazir et al. 2020a). But the research on the influencing factors of offshore wind power industry is very scarce. Based on the above four aspects, the 14 influencing factors of this paper are identified from literatures and expert interviews.

\section{Development status of offshore wind power}

\section{International situation}

At present, the total capacity of global offshore wind power exceeds $35 \mathrm{GW}$, increasing by $106 \%$ in the past 5 years. In 2020 , the new installed capacity of global offshore wind power exceeded $6 \mathrm{GW}$, which was second only to that in 2019 . As shown in Fig. 1, China's offshore wind power has led the world for three consecutive years, with a new installed capacity of $3.06 \mathrm{GW}$, accounting for $50.43 \%$ of the world's new installed capacity. Europe has maintained steady growth, accounting for most of the remaining new capacity. Specifically,

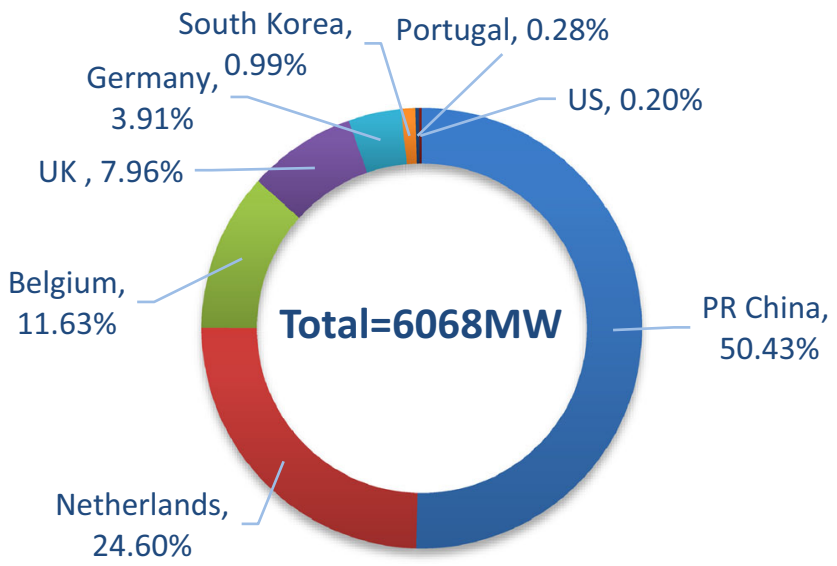

Fig. 1 Global annual offshore wind installations in 2020 (Data from Global wind report 2021 (Global Wind Energy Council (GWEC) 2021)) the annual new capacity of the Netherlands is second only to China, reaching $1493 \mathrm{MW}$; Belgium (706 MW), the UK (483 MW), and Germany (237 MW) also have new capacity; the new floating offshore wind power installation is only from Portugal (17 MW). As shown in Fig. 2, the cumulative installed capacity of China's offshore wind power exceeds that of Germany, second only to the UK, becoming the second-largest offshore wind power market in the world.

At present, Europe is still the largest offshore wind power market in the world, but the Asia Pacific region also pays more attention to offshore wind power. On December 15, 2020, Japan established the long-term goal of " $10 \mathrm{GW}$ by 2030 and 30-45 GW by 2040" for offshore wind power (CWEA 2020). South Korea announced that "by 2030, South Korea's offshore wind power scale will reach $12 \mathrm{GW}$, striving to become one of the top five offshore wind power countries in the world" (European offshore wind power 2020). In addition, the Biden government actively seeks to develop the state and company of offshore wind power industry and also vigorously develop the offshore wind power industry of the USA (Mackenzie 2020).

\section{Chinese situation}

Figure 3 shows the installed capacity of offshore wind power in China from 2010 to 2020. Only in 2011 and 2013 did the annual new installed capacity decline. Since 2013, the annual new installed capacity has been growing. Especially in recent years, China's offshore wind power industry is developing rapidly.

COVID-19 has formed a large-scale spread in early 2020, and many industries have suffered from adverse effects. However, the global offshore wind power industry still maintains a sustained growth trend during the epidemic period.

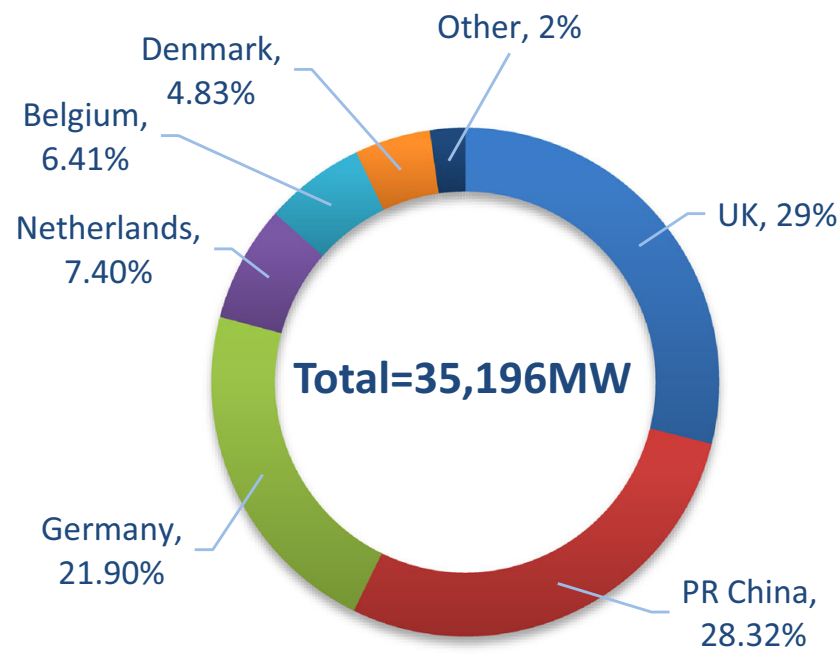

Fig. 2 Global cumulative offshore wind installations by end of 2020 . (Data from Global wind report 2021 (Global Wind Energy Council (GWEC) 2021)) 
Fig. 3 China's offshore wind power capacity in 2010-2020. Note: The data on the newly added and cumulative installed capacity of China's offshore wind power in each year are all from the Global Wind Energy Report of the GWEC over the years (Global Wind Energy Council (GWEC) 2019, 2020, 2021)

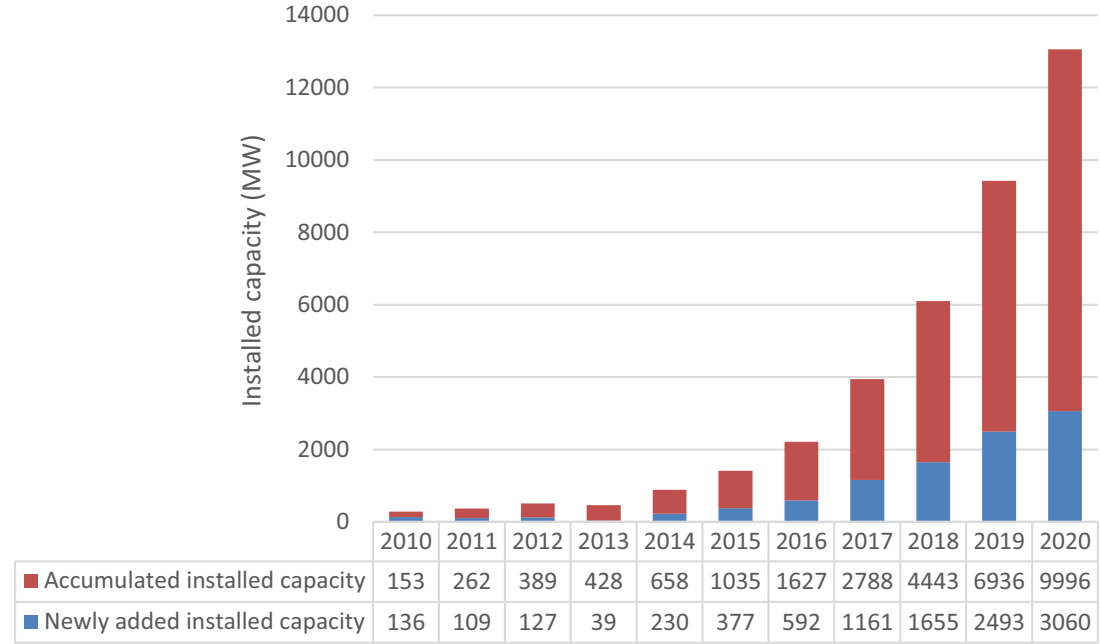

China's offshore wind power industry is even less affected by the epidemic.

The Chinese government attaches great importance to the significance of offshore wind power. As shown in Table 1 (Xu et al. 2021), in order to encourage and guide the healthy and sustainable development of offshore wind power and realize energy structure adjustment, the state has issued a series of planning policies to provide support and guidance for the development of offshore wind power. From the perspective of electricity prices, China has also issued a series of policies. On June 5, 2014, the National Development and Reform Commission (NDRC) issued the "Notice on Offshore Wind Power Feed-in Tariff Policy," stipulating that offshore wind power projects which put into operation before 2017 (excluding 2017) had a feed-in tariff of $0.85 \mathrm{yuan} / \mathrm{kWh}$, and the ongrid electricity price for projects in intertidal zone was 0.75 yuan $/ \mathrm{kWh}$. Since then, until 2019, in order to encourage the development of offshore wind power, the benchmark price of offshore wind power had remained unchanged. On May 21, 2019, the NDRC issued the "Notice on Improving the Policy for Wind Power Feed-in Tariffs." It is clear that "for offshore wind power projects approved before the end of 2018, if all units are connected to the grid before the end of 2021, the on grid price at the time of approval shall be implemented; for all units connected to the grid after 2022, the guiding price in the year of connection shall be implemented". To catch up with the feed in tariff deadline at the end of this year, China's offshore wind power construction boom is expected to continue in 2021.

\section{Methodology}

Warfield pioneered the ISM method in 1973 (Wang et al. 2020). Warfield explored the methodological questions of how frameworks of understanding and valuing could be developed for complex societal situations collectively. Warfield pointed out that the key dilemma in this exploration was that the rate of societal change was faster than the rate at which people can perform effectively in problem-solving and goal-setting situations. His explorations have yielded a way around this dilemma and an impressive theory of idea management (Warfield 1978). The basic theory of ISM is the reconstruction theory of graph theory, which belongs to static qualitative model. ISM has some limitations. First of all, there is no feedback loop between the levels, so we can only see the effect from the bottom to the top; second, the subjectivity is too strong, which depends on people's experience judgment to a certain extent, but this is also the inevitable disadvantage of all qualitative methods. However, compared with other quantitative methods, ISM still has irreplaceable advantages. It can present the fuzzy relationship with a clear structure model, so that people can more intuitively understand the complex relationship; and it is especially suitable for the system analysis with many variables, complex relationship between variables and unclear structure, and can also be used for the ranking of schemes. For example, "multiple regression" is a very classic method to study the relationship between variables. It can study the influence of a series of factors on a variable, but there is a certain subjectivity in the process of variable selection. In the face of many variables, "multiple regression" is very difficult to deal with. Some data are necessary but not available, which will make the "multiple regression" research unable to advance.

The interpretative structural model decomposes a complex system into several sub-system elements and constructs a multi-level hierarchical structure model by combining people's practice, knowledge and experience, and computer assistance (Jia 2020). Using interpretative structural model to analyze, we can find out the surface direct influencing factors, the middle indirect influencing factors, and the deep fundamental influencing factors from many influencing factors and 


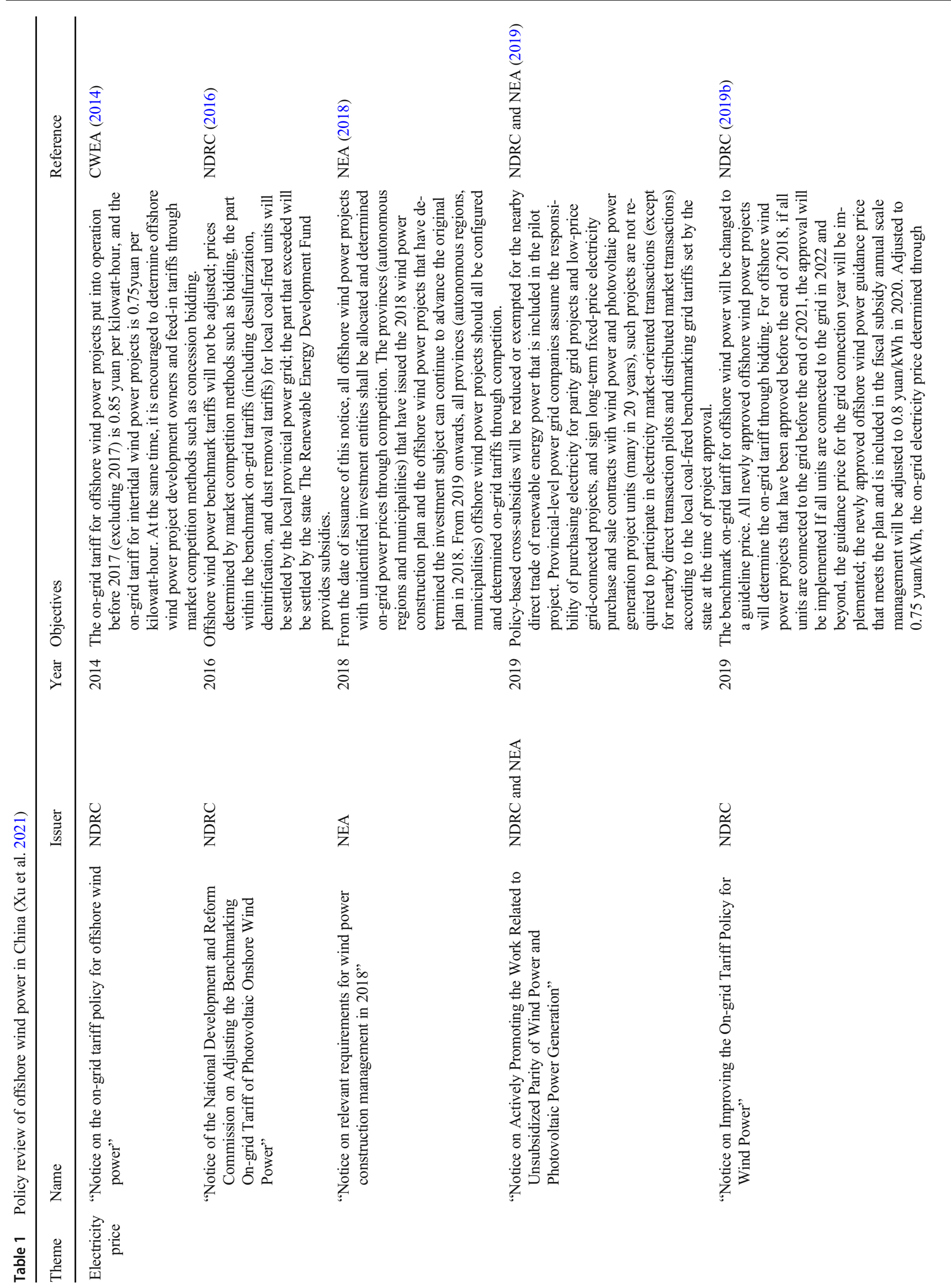




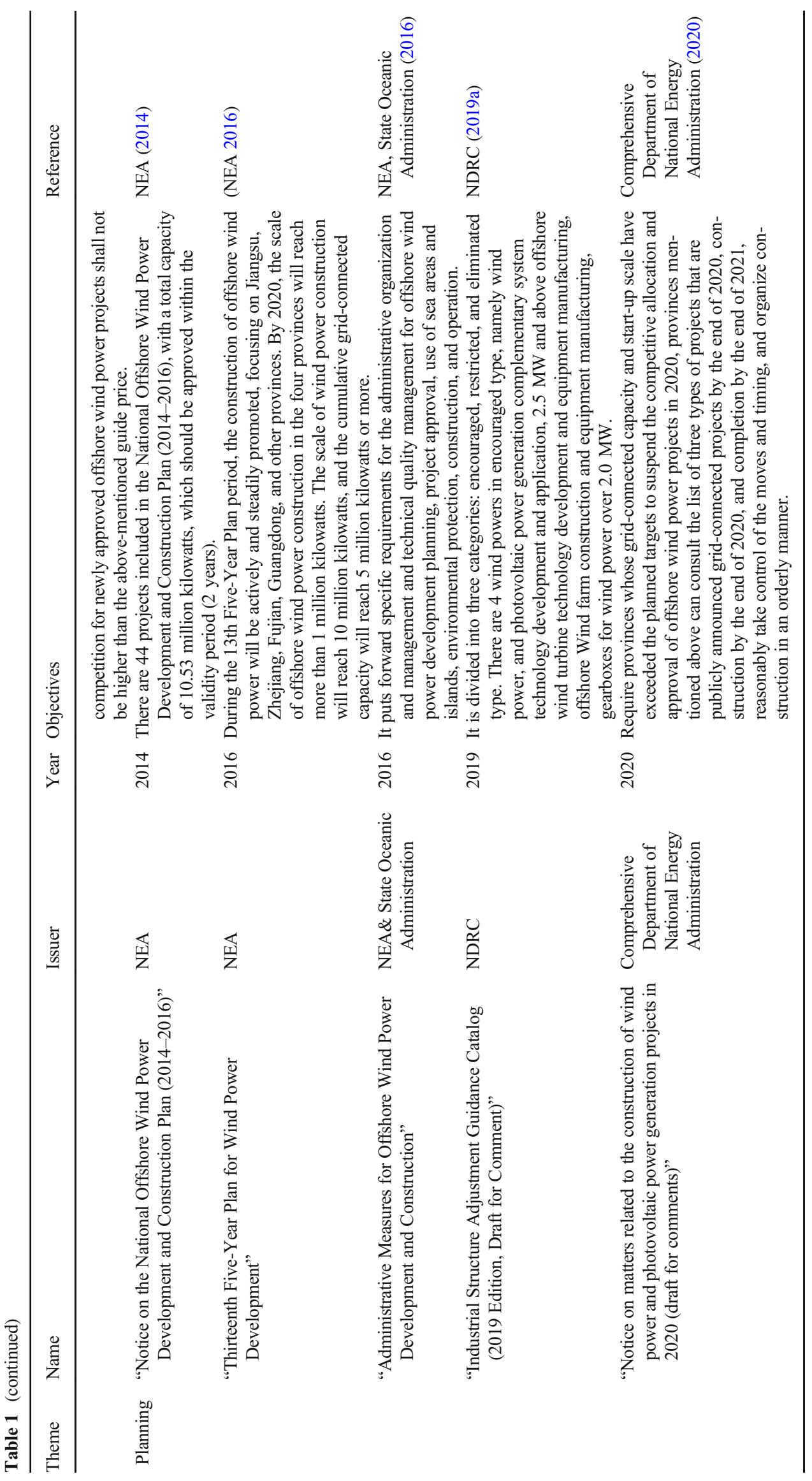


complex factor chains (Xue and Liu 2008). The explanatory structure model plays an important role in system engineering, which is the middle part of the transition from conceptual model to quantitative model. It is widely used in systems that are difficult to quantify directly and has been successfully applied in risk management (Li et al. 2007), power demand (Xu et al. 2009), and other fields, and its modeling steps are as follows (Xu et al. 2009; Wang and Kang 2017; Mathiyazhagan et al. 2013; Xu and Zou 2020). The flowprocess diagram of the ISM model is shown in Fig. 4.

Step 1: Determine the system factor set. Collect all the components related to the system, and classify and arrange them to form a set containing $\mathrm{n}$ elements, which is determined as the system factor set $S$, which is recorded as:

$S=\left\{S_{i} \mid(i=1,2, \cdots, n)\right\}$

Step 2: Establish a concept system. Associate each element in the system factor set with other (n-1) elements to judge whether there is a direct binary relationship between them, which can be expressed as:

$a_{i j}=\left\{\begin{array}{lll}1 & \left(S_{i} \text { has an }\right. & \left.\text { effect on } S_{j} .\right) \\ 0 & \left(S_{i} \text { has an }\right. & \left.\text { effecton } S_{j} .\right)\end{array}\right.$

$0\left(S_{i}\right.$ has no effect on $\left.S_{j}\right)$

Step 3: Form an adjacency matrix. Arranging all the direct binary relations to obtain an n-order matrix, which is called adjacency matrix $A$ and expressed as $A=(a i j) M \times N$.

Fig. 4 Flow-process diagram of ISM model
Step 4: Calculate the reachability matrix. $A$ is a direct binary relationship between elements. After transmission, some elements may establish an indirect influence relationship. Find out all the indirect transmission relationships and get the reachability matrix $M$, whose calculation formula is:

$(A+I) \neq(A+I)^{2} \neq \cdots \neq(A+I)^{m}=(A+I)^{m+1}=M$

According to the operational rule of Boolean algebra, $A$ is first added with identity matrix $I$, and then multiplied by itself. When the result of multiplication will not change again, the $M$ obtained at this time is the reachability matrix.

Step 5: Hierarchical division. Find the reachable set $P$ and antecedent set $Q$ of all elements. If $P\left(S_{i}\right) \cap Q\left(S_{i}\right)=P\left(S_{i}\right)$, this element is a high-level element, the elements meeting this condition are of the same level, and so on, different hierarchical levels are obtained.

Step 6: Generate a hierarchical topology diagram. After the hierarchical division is completed, the directed connection graph is drawn, which can directly and clearly represent the hierarchical structure of the system.

\section{The influencing factors of offshore wind power industry in China based on ISM model}

\section{Applicability analysis}

There are three bases for using ISM method in this paper: (1) offshore wind power industry is a complex system involving cross knowledge of energy, economy, and other aspects. ISM

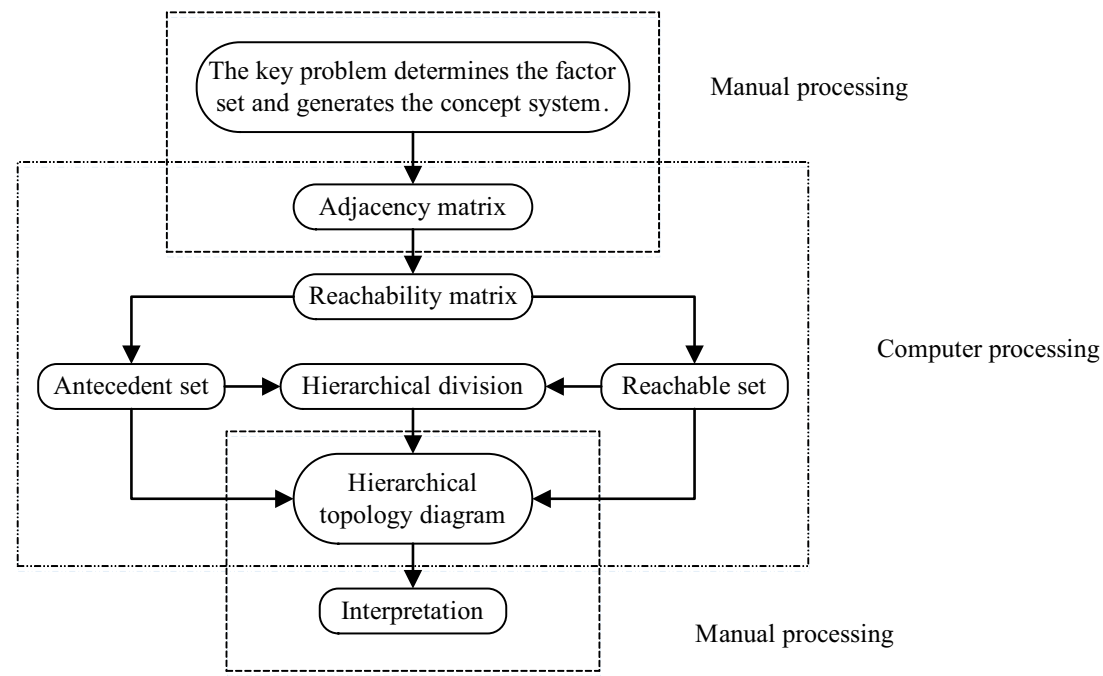


is suitable for the interpretation and analysis of dynamic systems with many variables, complex relationships, and fuzzy structure. It can decompose a complex system into several subsystems with the help of researchers' practical experience and professional knowledge (Shen et al. 2021). (2) Offshore wind power industry is affected by many factors such as policy, technology, resources and environment, and market supply and demand. ISM can classify, identify, and select the key factors affecting offshore wind power industry, and deeply analyze the characteristics and hierarchical relationship of each key factor. (3) Compared with the empirical analysis of other influencing factors, ISM can continuously supplement the arguments according to the research progress, ensure the timeliness, strictness, and saturation of the data, and enhance the persuasiveness of the research conclusions (Liu 2017).

\section{Determination of the influencing factors set}

According to GWEC's data (GWEC 2021), in 2020, China's new installed capacity of offshore wind power reached $3060 \mathrm{MW}$, ranking the first in the world. The cumulative installed capacity reached $9996 \mathrm{MW}$, ranking the second in the world. China's offshore wind power has not only made great achievements in the installed capacity but also made a great breakthrough in technology. On July 12, 2020, China's first 10-MW offshore wind turbine was successfully connected to the grid for power generation at Three Gorges Group, Fujian Fuqing, Xinghua Bay Phase II offshore wind farm. The grid-connected power generation marks that China has independent design, research and development, manufacturing, installation, debugging, and operation capabilities of $10 \mathrm{MW}$ large-capacity offshore wind turbines. It also marks a historic progress for China's wind power development capabilities and a great achievement in realizing the localization of major offshore wind power equipment (China Three Gorges Group Corporation 2020). In recent years, although China's offshore wind power industry has made great progress, it is still in the exploratory development stage, facing the constraints of policy, technology, environment, and market. There are still many problems to be solved. The site selection of offshore wind farm is a key step in the development of offshore wind power, which involves a lot of planning, and needs the coordination from provincial functional departments to local municipal government functional departments (Polaris wind power network 2018); offshore wind power and ecological environment are important factors for the location of wind farm. Wind turbine is the lifeblood of wind power generation. In the face of harsh marine environment, the reliability of wind turbine will be greatly reduced, resulting in high operation and maintenance costs of offshore wind power. Michiel et al. (2019) discovered that the cost of operation and maintenance stage accounts for about $30 \%$ of the total cost of offshore wind power generation. This has greatly hindered the large-scale development of offshore wind power industry. From the perspective of the industrial chain, there is no obvious difference between offshore wind power and onshore wind power, which can be divided into three parts from bottom to top: wind farm operation, wind turbine manufacturing and wind turbine parts manufacturing (China Investment Advisory Network 2018). The operation of the industrial chain has a great impact on the development of the whole offshore wind power industry: the operation of wind farms is affected by policy factors, and it also has a direct impact on the cost of power generation; wind turbine manufacturing is affected by policy factors and R\&D input costs, and controlling the cost of wind turbine manufacturing technology is the key to reduce the cost of offshore wind power generation.

There are many and complex factors influencing offshore wind power industry, which are affected by economic development, policy situation, technological innovation, resource environment, market supply and demand, etc. In this paper, through literature retrieval method, the factors that can affect offshore wind power are obtained, and then through expert consultation method, the influencing factor set is further determined, including 14 factors: development planning, on-grid electricity price, economic incentive policy, environmental protection policy, operation mechanism, operation management, offshore wind power technology, offshore wind resource supply, site selection, power generation cost, R\&D investment, industrial chain, energy market mechanism, investment, and financing mechanism. The direct binary relationship among the influencing factors is shown in Table 2.

\section{Adjacency matrix and reachability matrix}

The 14 influencing factors listed in Table 2 and their direct binary relations are expressed by formula (2), and a matrix $A$ of $14 \times 14$ is obtained, which is the adjacency matrix of the influencing factor set, as shown in Table 3.

Run the program after inputting the adjacency matrix in Matlab2018a software. When iterating for five times, the matrix reaches a stable state, then exit the loop and get the reachability matrix, arrange the reachability matrix in ascending order according to rows, adjust the column direction accordingly, and divide the hierarchy to get the reachability matrix with clear hierarchy, as shown in Table 4.

\section{Results and discussions}

\section{Matrix decomposition results}

Hierarchical decomposition is based on the analysis of antecedent set, reachable set, and their intersection set. The antecedent set $Q$ is the set of factors that can influence $S_{i}$ through direct or indirect conduction. Reachable set $P$ is the set of 


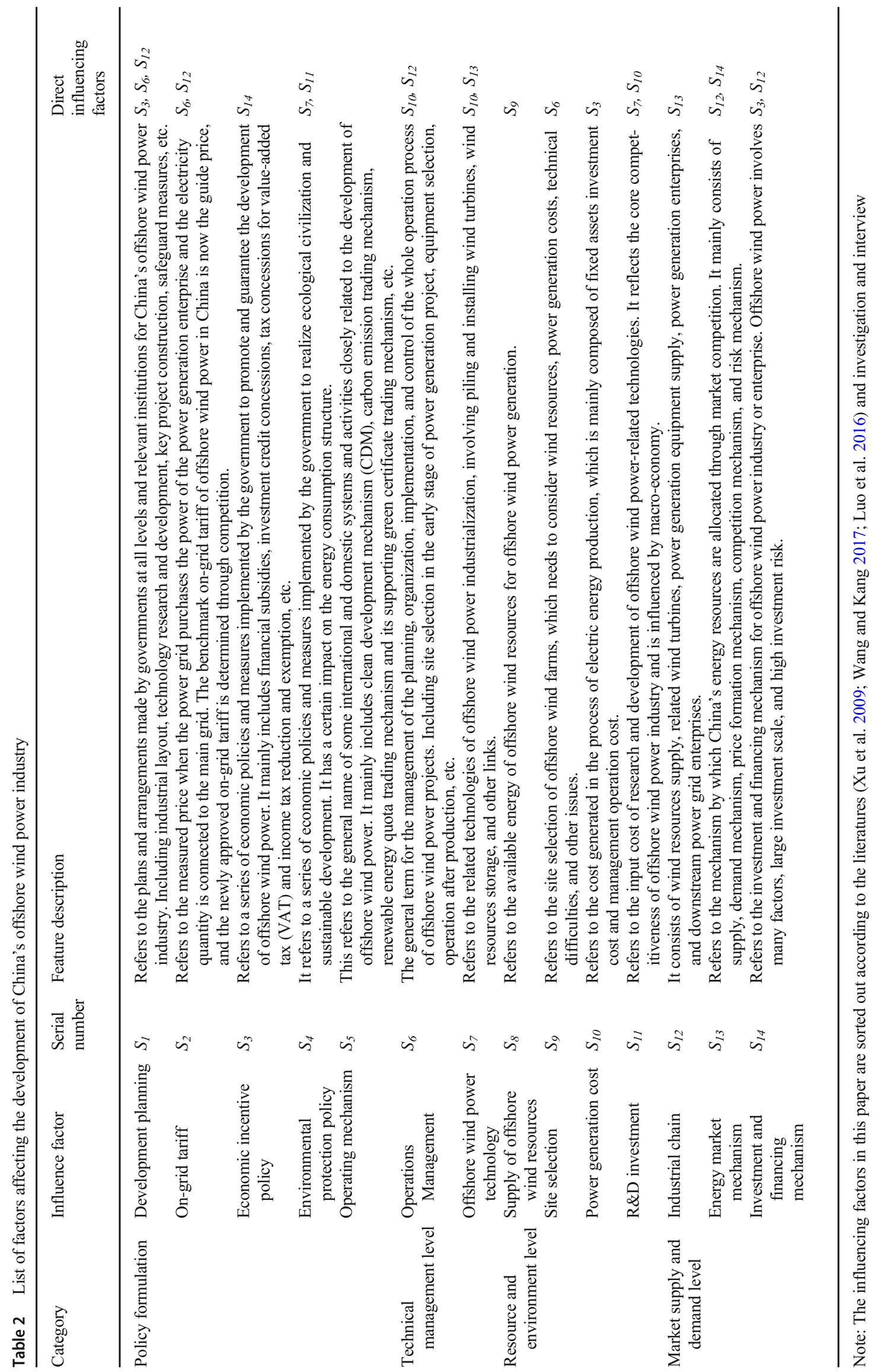


Table 3 Adjacency matrix $A$

$\begin{array}{llllllllllllll}\mathrm{S}_{1} & \mathrm{~S}_{2} & \mathrm{~S}_{3} & \mathrm{~S}_{4} & \mathrm{~S}_{5} & \mathrm{~S}_{6} & \mathrm{~S}_{7} & \mathrm{~S}_{8} & \mathrm{~S}_{9} & \mathrm{~S}_{10} & \mathrm{~S}_{11} & \mathrm{~S}_{12} & \mathrm{~S}_{13} & \mathrm{~S}_{14}\end{array}$ $\begin{array}{lllllllllllllll}\mathrm{S}_{1} & 0 & 0 & 1 & 0 & 0 & 1 & 0 & 0 & 0 & 0 & 0 & 1 & 0 & 0\end{array}$ $\begin{array}{lllllllllllllll}\mathrm{S}_{2} & 0 & 0 & 0 & 0 & 0 & 1 & 0 & 0 & 0 & 0 & 0 & 1 & 0 & 0\end{array}$ $\begin{array}{lllllllllllllll}\mathrm{S}_{3} & 0 & 0 & 0 & 0 & 0 & 0 & 0 & 0 & 0 & 0 & 0 & 0 & 0 & 1\end{array}$ $\begin{array}{lllllllllllllll}\mathrm{S}_{4} & 0 & 0 & 0 & 0 & 0 & 0 & 1 & 0 & 0 & 0 & 1 & 0 & 0 & 0\end{array}$

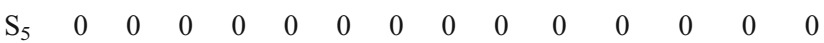
$\begin{array}{lllllllllllllll}\mathrm{S}_{6} & 0 & 0 & 0 & 0 & 0 & 0 & 0 & 0 & 0 & 1 & 0 & 1 & 0 & 0\end{array}$ $\begin{array}{lllllllllllllll}\mathrm{S}_{7} & 0 & 0 & 0 & 0 & 0 & 0 & 0 & 0 & 0 & 1 & 0 & 0 & 1 & 0\end{array}$ $\begin{array}{lllllllllllllll}\mathrm{S}_{8} & 0 & 0 & 0 & 0 & 0 & 0 & 0 & 0 & 1 & 0 & 0 & 0 & 0 & 0\end{array}$ $\begin{array}{lllllllllllllll}\mathrm{S}_{9} & 0 & 0 & 0 & 0 & 0 & 1 & 0 & 0 & 0 & 0 & 0 & 0 & 0 & 0\end{array}$

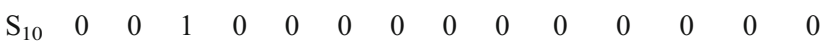

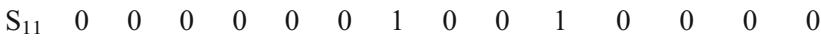
$\begin{array}{lllllllllllllll}\mathrm{S}_{12} & 0 & 0 & 0 & 0 & 0 & 0 & 0 & 0 & 0 & 0 & 0 & 0 & 1 & 0\end{array}$ $\begin{array}{lllllllllllllll}\mathrm{S}_{13} & 0 & 0 & 0 & 0 & 0 & 0 & 0 & 0 & 0 & 0 & 0 & 1 & 0 & 1\end{array}$ $\begin{array}{lllllllllllllll}\mathrm{S}_{14} & 0 & 0 & 1 & 0 & 0 & 0 & 0 & 0 & 0 & 0 & 0 & 1 & 0 & 0\end{array}$

factors that can be reached by conducting $S_{i}$ directly or indirectly (Wang et al. 2017). According to the $M$, the reachable set $P$, antecedent set $Q$, and their intersection set are shown in Table 5.

\section{Directed graph of hierarchical structure}

Enter the reachability matrix in Matlab2018a and run the program, and the hierarchical decomposition can be calculated as shown in Table 6. Hierarchical division is to better understand the hierarchical relationship between various factors in the system and the influence degree of each factor. The toplevel represents the ultimate goal of the system, and the lower level is the reason for the upper level. The bottom factors are the root cause of system motion.

Table 4 Reachability matrix $M$

\begin{tabular}{|c|c|c|c|c|c|c|c|c|c|c|c|c|c|c|c|}
\hline & $\mathrm{S}_{3}$ & $\mathrm{~S}_{5}$ & $\mathrm{~S}_{12}$ & $\mathrm{~S}_{13}$ & $\mathrm{~S}_{14}$ & $\mathrm{~S}_{10}$ & $\mathrm{~S}_{6}$ & $\mathrm{~S}_{7}$ & $\mathrm{~S}_{1}$ & $\mathrm{~S}_{2}$ & $\mathrm{~S}_{9}$ & $\mathrm{~S}_{11}$ & $\mathrm{~S}_{4}$ & $\mathrm{~S}_{8}$ & \\
\hline $\mathrm{S}_{3}$ & 1 & 0 & 1 & 1 & 1 & 0 & 0 & 0 & 0 & 0 & 0 & 0 & 0 & 0 & \\
\hline $\mathrm{S}_{5}$ & 0 & 1 & 0 & 0 & 0 & 0 & 0 & 0 & 0 & 0 & 0 & 0 & 0 & 0 & \\
\hline$S_{12}$ & 1 & 0 & 1 & 1 & 1 & 0 & 0 & 0 & 0 & 0 & 0 & 0 & 0 & 0 & \\
\hline$S_{13}$ & 1 & 0 & 1 & 1 & 1 & 0 & 0 & 0 & 0 & 0 & 0 & 0 & 0 & 0 & \\
\hline$S_{14}$ & 1 & 0 & 1 & 1 & 1 & 0 & 0 & 0 & 0 & 0 & 0 & 0 & 0 & 0 & \\
\hline$S_{10}$ & 1 & 0 & 1 & 1 & 1 & 1 & 0 & 0 & 0 & 0 & 0 & 0 & 0 & 0 & \\
\hline $\mathrm{S}_{6}$ & 1 & 0 & 1 & 1 & 1 & 1 & 1 & 0 & 0 & 0 & 0 & 0 & 0 & 0 & \\
\hline$S_{7}$ & 1 & 0 & 1 & 1 & 1 & 1 & 0 & 1 & 0 & 0 & 0 & 0 & 0 & 0 & \\
\hline S & 1 & 0 & 1 & 1 & 1 & 1 & 1 & 0 & 1 & 0 & 0 & 0 & 0 & 0 & \\
\hline S & 1 & 0 & 1 & 1 & 1 & 1 & 1 & 0 & 0 & 1 & 0 & 0 & 0 & 0 & \\
\hline N9 & 1 & 0 & 1 & 1 & 1 & 1 & 1 & 0 & 0 & 0 & 1 & 0 & 0 & 0 & \\
\hline $\mathrm{S}_{11}$ & 1 & 0 & 1 & 1 & 1 & 1 & 0 & 1 & 0 & 0 & 0 & 1 & 0 & 0 & \\
\hline $\mathrm{S}_{4}$ & 1 & 0 & 1 & 1 & 1 & 1 & 0 & 1 & 0 & 0 & 0 & 1 & 1 & 0 & \\
\hline 8 & 1 & 0 & 1 & 1 & 1 & 1 & 1 & 0 & 0 & 0 & 1 & 0 & 0 & 1 & \\
\hline
\end{tabular}

\section{Establishment and analysis of ISM}

It can be seen from the hierarchical structure model (Table 6 and Fig. 5) that the influencing factors of offshore wind power industry can be divided into five levels.

First, all the influencing factors ultimately point to five factors: economic incentive policy $\left(S_{3}\right)$, operation mechanism $\left(S_{5}\right)$, industrial chain $\left(S_{12}\right)$, energy market mechanism $\left(S_{13}\right)$, and investment and financing mechanism $\left(S_{14}\right)$ through different ways and means. Therefore, these five factors are the direct causes affecting the offshore wind power industry, which are surface factors. Compared with other renewable energy sources, the generation cost of offshore wind power is higher and the development is more difficult, which leads to greater investment risks. In this case, the economic incentive policies composed of financial subsidies, tax incentives, electricity price subsidies, and investment incentives, as well as the operation mechanism composed of clean development mechanism, carbon emission trading mechanism, renewable energy quota trading mechanism, and its supporting green certificate trading mechanism are particularly important to ensure the operation and promotion of offshore wind power industry. This is also a significant "high push" effect. The decision-making of the state and relevant departments determines the implementation and resource allocation of offshore wind power industry. Economic support directly stimulates industrial development, and operation mechanism is the driving force of industrial development. In addition, industrial chain, energy market mechanism, investment, and financing mechanism also have a direct impact on the development of offshore wind power industry. The supply and demand of the market is the best signal for the development of offshore wind power industry. Good market supply and demand relationship

Table 5 Table of reachable set, antecedent set, and their intersection set

\begin{tabular}{llll}
\hline$S_{i}$ & $P\left(S_{i}\right)$ & $Q\left(S_{i}\right)$ & $P\left(S_{i}\right) \cap Q\left(S_{i}\right)$ \\
\hline$S_{1}$ & $1,3,6,10,12,13,14$ & 1 & 1 \\
$S_{2}$ & $2,3,6,10,12,13,14$ & 2 & 2 \\
$S_{3}$ & $3,12,13,14$ & $1,2,3,4,6,7,8,9,10,11,12,13,14$ & $3,12,13,14$ \\
$S_{4}$ & $3,4,7,10,11,12,13,14$ & 4 & 4 \\
$S_{5}$ & 5 & 5 & 5 \\
$S_{6}$ & $3,6,10,12,13,14$ & $1,2,6,8,9$ & 6 \\
$S_{7}$ & $3,7,10,12,13,14$ & $4,7,11$ & 7 \\
$S_{8}$ & $3,6,8,9,10,12,13,14$ & 8 & 8 \\
$S_{9}$ & $3,6,9,10,12,13,14$ & 8,9 & 9 \\
$S_{10}$ & $3,10,12,13,14$ & $1,2,4,6,7,8,9,10,11$ & 10 \\
$S_{11}$ & $3,7,10,11,12,13,14$ & 4,11 & 11 \\
$S_{12}$ & $3,12,13,14$ & $1,2,3,4,6,7,8,9,10,11,12,13,14$ & $3,12,13,14$ \\
$S_{13}$ & $3,12,13,14$ & $1,2,3,4,6,7,8,9,10,11,12,13,14$ & $3,12,13,14$ \\
$S_{14}$ & $3,12,13,14$ & $1,2,3,4,6,7,8,9,10,11,12,13,14$ & $3,12,13,14$ \\
\hline
\end{tabular}


Table 6 Hierarchical decomposition of factors

\begin{tabular}{ll}
\hline Hierarchy & Influencing factor \\
\hline First level & $S_{3}, S_{5}, S_{12}, S_{13}, S_{14}$ \\
Second level & $S_{10}$ \\
Third level & $S_{6}, S_{7}$ \\
Fourth level & $S_{1}, S_{2}, S_{9}, S_{11}$ \\
Fifth level & $S_{4}, S_{8}$ \\
\hline
\end{tabular}

can make the offshore wind power industry maintain sustainable and stable development.

Secondly, three factors, namely, power generation cost $\left(S_{10}\right)$, operation management $\left(S_{6}\right)$ and offshore wind power technology $\left(S_{7}\right)$, are intermediate factors. Among them, operation management and offshore wind power technology are important factors that affect the supply of offshore wind power. The level of professional technology and operation management determine the development quality of the supply side of offshore wind power industry. And power generation cost is an important factor that affects the demand of offshore wind power. The higher the generation cost, the higher the electricity price. And high electricity prices will lead to a reduction in demand. On the other hand, if the offshore wind power project can achieve better operation and management and make continuous progress in offshore wind power technology, it will definitely reduce the power generation cost of offshore wind power, thus better developing the offshore wind power industry.

Thirdly, development planning $\left(S_{1}\right)$, on-grid electricity price $\left(S_{2}\right)$, site selection $\left(S_{9}\right), \mathrm{R} \& \mathrm{D}$ investment $\left(S_{11}\right)$, environmental protection policy $\left(S_{4}\right)$, and offshore wind resources supply $\left(S_{8}\right)$ are all deep-seated factors affecting offshore wind power industry. Development planning policy and environmental protection policy affect the layout and progress of the whole offshore wind power industry. Development planning policy helps to promote the offshore wind power industry in an orderly manner, while environmental protection policy can play a very good incentive role for the offshore wind power industry. The supply of offshore wind resources determines the site selection, and it is also a necessary condition for the development of offshore wind power industry. But this factor is often ignored. Therefore, the assessment of offshore wind resources should be paid more attention. The input cost of $\mathrm{R} \& \mathrm{D}$ is a part of the total cost, which is an indispensable financial support for technology improvement. At the same time, it affects the grid price.

\section{Conclusions}

As a kind of green energy, offshore wind power industry has made great achievements in recent years and stands out in renewable energy. Due to the abundant offshore wind energy resources, there is of great development potential for offshore wind power. However, the offshore wind power industry has encountered new bottlenecks, so it is necessary to deeply analyze the influencing factors of offshore wind power industry development. ISM model is a method to analyze the hierarchical relationship between influencing factors. Firstly, the influencing factor set of offshore wind power industry must be determined. Offshore wind power industry is affected by many factors, such as economic development, policy situation, technological innovation, resource environment, and
Fig. 5 Hierarchical topology diagram of influencing factors of offshore wind power industry

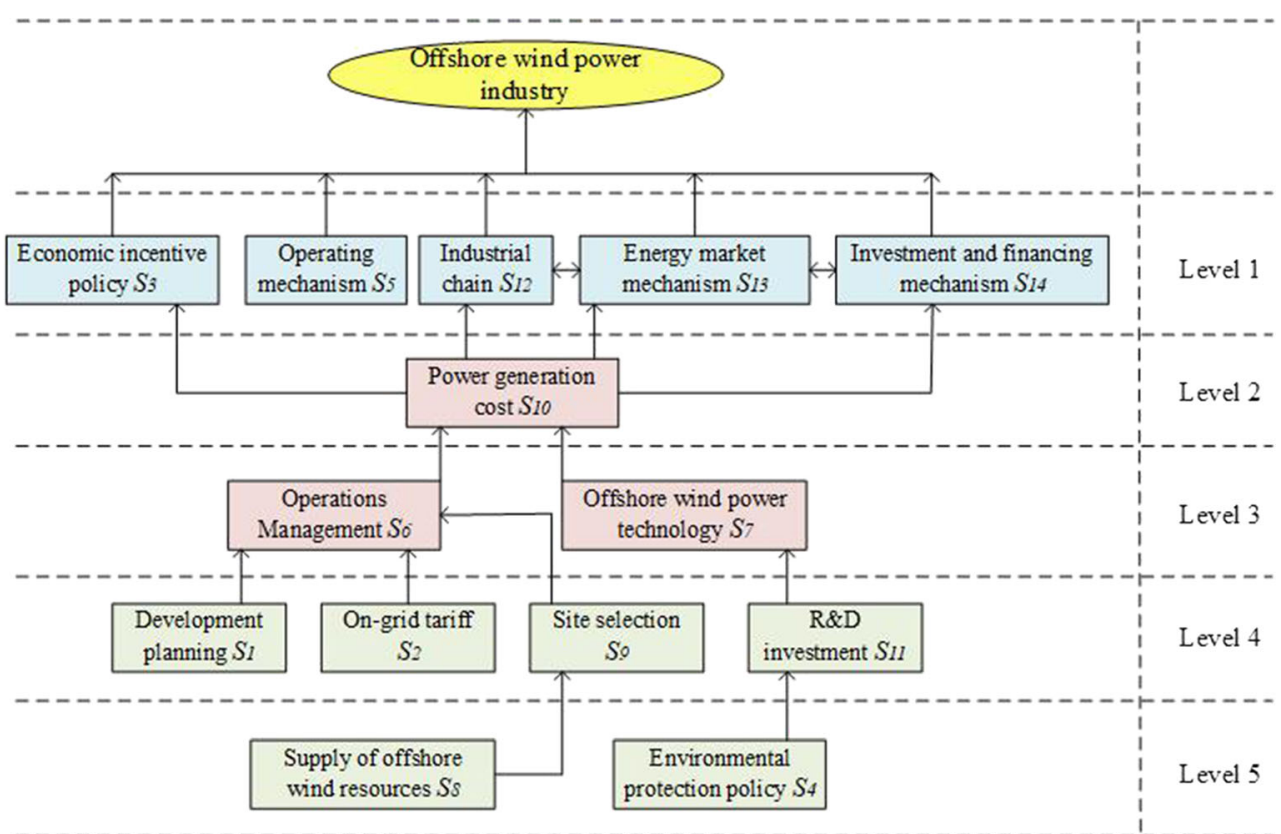


market supply and demand. Through literature search and expert consultation, 14 influencing factors were identified. By analyzing the 14 factors with the ISM model, these factors can be divided into five levels. Among them, the factors in the first level classified as the surface factors, including economic incentive policy $\left(S_{3}\right)$, operation mechanism $\left(S_{5}\right)$, industrial chain $\left(S_{12}\right)$, energy market mechanism $\left(S_{13}\right)$, and investment and financing mechanism $\left(S_{14}\right)$. The factors in the second and third level classified as the intermediate factors, including power generation cost $\left(S_{10}\right)$, operation management $\left(S_{6}\right)$, and offshore wind power technology $\left(S_{7}\right)$. The factors in the fourth and fifth level classified as the deep-seated factors. They include six factors: development planning $\left(S_{1}\right)$, on-grid electricity price $\left(S_{2}\right)$, site selection $\left(S_{9}\right)$, R\&D investment $\left(S_{11}\right)$, environmental protection policy $\left(S_{4}\right)$, and offshore wind resources supply $\left(S_{8}\right)$.

China's offshore wind power industry is now in a critical period of development. On the one hand, China's offshore wind resources are very rich, and offshore wind power has good ecological and social benefits, and offshore wind power occupies an irreplaceable absolute dominant position in renewable energy; On the other hand, offshore wind power still has some technical problems and inevitable uncertainties such as climate, which makes the economy of offshore wind power in renewable energy at a disadvantage. There are many factors affecting the development of offshore wind power industry, including objective environmental factors and artificial factors. The surface factors and deep-seated factors need to be paid close attention in order to clear the obstacles for the development of offshore wind power industry.

According to the influencing factors, the policy recommendations are shown as follow:

First, at the level of policy support, the policy system of offshore wind power industry should be improved. China's offshore wind power industry has not yet reached the mature stage, so the government needs to formulate corresponding supportive policies. The policies of offshore wind power industry should cover development planning, on-grid tariff, technology research and development, taxation, subsidies, investment and financing, etc. For example, in terms of technology research and development, increase research and development funds for key technologies such as offshore wind power generators, blades, and unit converters, or encourage key technology development by providing discount loans and establish subsidies for offshore wind power machinery purchase; another example is to further improve credit policies and increase preferential efforts in offshore wind power investment and financing; carry out rolling development planning, regularly check whether the plan is completed, and make timely and reasonable adjustments to the plan.

Second, at the level of technology management and resource environment, decision-makers should pay more attention to wind resources assessment and site selection; develop more offshore wind power projects suitable for construction, investment, and operation and stop projects with insufficient or extremely unstable wind resources in time; more attention should be paid to R\&D investment of offshore wind power. Technology is the primary productivity of offshore wind power industry and plays a key role in the better development of offshore wind power.

Third, at the level of market supply and demand, government departments should guide the whole offshore wind power industry chain to develop healthily and encourage enterprises to invest and finance offshore wind power projects, so as to speed up the development of offshore wind power industry, and guide the supply and demand mechanism, price formation mechanism, competition mechanism and risk mechanism to ensure the large-scale and commercial promotion of offshore wind power industry.

Availability of data and materials All data generated or analyzed during this study are included in this published article.

Author contribution All authors contributed to the study conception and design. Data collection and analysis were performed by K.Y and G.Z. The first draft of the manuscript was written by Y.X and all authors commented on previous versions of the manuscript. All authors read and approved the final manuscript.

Funding This study was funded by the National Natural Science Foundation of China (71774105), Program for the Innovative Talents of Higher Education Institutions of Shanxi (PTIT), and Program for the Philosophy and Social Sciences Research of Higher Learning Institutions of Shanxi (2020W061). The authors would also like to acknowledge great thanks to anonymous reviewers for their valuable comments which largely improve the academic quality of this paper. The usual caveats apply.

\section{Declarations}

Ethical approval Not applicable.

Consent to participate Not applicable.

Consent to publish Not applicable.

Competing interests The authors declare no competing interests.

\section{References}

Allouhi A, Zamzoum O, Islam MR, Saidur R, Kousksou T, Jamil A, Derouich A (2017) Evaluation of wind energy potential in Morocco's coastal regions. Renew Sust Energ Rev 72:311-324. https://doi.org/10.1016/j.rser.2017.01.047

Bains H, Madariaga A, Troffaes M, Kazemtabrizi B (2020) An economic model for offshore transmission asset planning under severe uncertainty. Renew Energy 160:1174-1184. https://doi.org/10.1016/j. renene. 2020.05 .160 
Cao R (2018) A model based on technology diffusion for studying on factors affecting the wind power development. Dissertation, Tianjin University

Chen H, Tang T, Ait-Ahmed N, Benbouzid MEH, Zaim ME (2018) Attraction, challenge and current status of marine current energy. IEEE Access 6:12665-12685. https://doi.org/10.1109/ACCESS. 2018.2795708

China Investment Advisory Network (2018) Analysis of offshore wind power market prospect and industrial chain pattern. http://news. bjx.com.cn/html/20180930/931624-2.shtml. Accessed 21 October 2020

China Three Gorges Group Corporation (2020) The largest single capacity offshore wind turbine in Asia Pacific was successfully connected to the grid in Xinghua Bay wind farm of Fuqing, Three Gorges http://www.sasac.gov.cn/n2588025/n2588124/c15099346/content. $\mathrm{html}$. Accessed 20 July 2020

Chinese Wind Energy Association (CWEA) (2014) Notice on the on-grid tariff policy for offshore wind power. Polaris Wind Power Web. http://news.bjx.com.cn/html/20140617/519149.shtml . Accessed 20 June 2020

Comprehensive Department of National Energy Administration (2020) Notice on matters related to the construction of wind power and photovoltaic power generation projects in 2020 (draft for comments). Official website of NEA.. http://www.nea.gov.cn/2020-01/ 23/c 138728958.htm . Accessed 20 June 2020

Cranmer A, Baker E, Liesiö J, Salo A (2017) A portfolio model for siting offshore wind farms with economic and environmental objectives. Eur J Oper Res 000:1-11. https://doi.org/10.1016/j.ejor. 2017.11.026

CWEA (2020) Japan's goal of upgrading offshore wind power: $10 \mathrm{GW}$ by 2030 and $30-45 \mathrm{GW}$ by 2040 . International energy web. https:// www.in-en.com/article/html/energy-2299375.shtml accessed 28 march 2021

Dedecca JG, Hakvoort RA, Ortt JR (2016) Market strategies for offshore wind in Europe: a development and diffusion perspective. Renew Sust Energ Rev 66:286-296. https://doi.org/10.1016/j.rser. 2016.08.007

European offshore wind power (2020) 120 trillion won will be invested in the next five years and the scale of offshore wind power in South Korea will reach $12 \mathrm{GW}$ by 2030 . Polaris Wind Power Web. http:// news.bjx.com.cn/html/20200720/1090272.shtml Accessed 28 March 2021

Global Wind Energy Council (GWEC) (2019) Global wind report 2018. Brussels, Belgium

Global Wind Energy Council (GWEC) (2020) Global wind report 2019. Brussels, Belgium

Global Wind Energy Council (GWEC) (2021) Global wind report 2021. Brussels, Belgium

Guo QY, Huang R, Zhuang LW, Zhang KY, Huang JF (2019) Assessment of China's offshore wind resources based on the integration of multiple satellite data and meteorological data. Remote Sens 11:2680. https://doi.org/10.3390/rs11222680

International Renewable Energy Agency (2019) Future of wind. https:// wwwirenaorg/-/media/Files/IRENA/Agency/Publication/2019/Oct/ IRENA Future of wind 2019pdf Accessed 25 March 2021

Ji PC, Gao S, Shi HQ, Tang Y (2019) How to develop offshore wind power better in the face of fierce market competition. Editorial Department of wind energy industry of wind energy equipment branch of China Agricultural Machinery Industry Association, China Agricultural Machinery Industry Association wind machinery branch

Jia F (2020) An urban traffic congestion analysis based on the interpretive structure model and MICMAC. Journal of Hebei University (Natural Science Edition) 40:344-350. https://doi.org/10.3969/j. issn.1000-1565.2020.04.002
Kisvari A, Lin Z, Liu X (2020) Wind power forecasting - a data-driven method along with gated recurrent neural Network. Renew Energy 163:1895-1909. https://doi.org/10.1016/j.renene.2020.10.119

Li LM (2021) Global offshore wind power meets new "bottleneck". China Energy News. https://baijiahao.baidu.com/s?id= $1687950873192517434 \& \mathrm{wfr}=$ spider $\&$ for $=$ pc. Accessed 6 January 2021

Li HF, Tan ZF, Wang CW, Han JS (2007) Interpretative structural model based risk structural analysis of power generation company in electricity market. Power System Technology. 9-64. https://doi.org/10. 3321/j.issn:1000-3673.2007.13.012

Liu ZY (2017) Ambidexterous knowledge integration, entrepreneurial capability and high-tech new venture performance. Studies in Science of Science 35:272-281. https://doi.org/10.16192/j.cnki. 1003-2053.2017.02.014

Liu ZF, Zhang WH, Zhao CH, Yuan JH (2015) The economics of wind power in China and policy implications. Energies 8:1529-1546. https://doi.org/10.3390/en8021529

Luo BH, Zhang CH, Niu ZL (2016) Research on factors of biomass power industry in semi-arid areas based on ISM model. Issues of Forestry Economics 36:162-168. https://doi.org/10.16832/j.cnki. 1005-9709.2016.02.012

Mackenzie W (2020) Biden administration's five major impacts on the U.S. energy industry. Polaris wind power web. http:// guangfu.bjx.com.cn/news/20201117/1116412.shtml accessed 28 march 2021

Mathiyazhagan K, Govindan K, NoorulHag A, Geng Y (2013) An ISM approach for the barrier analysis in implementing green supply chain management. J Clean Prod 47:283-297. https://doi.org/10.1016/j. jclepro.2012.10.042

Michiel AJ, Veldman J, Fazi S, Greijdanus R (2019) Evaluating resource sharing for offshore wind farm maintenance: the case of jack-up vessels. Renew Sust Energ Rev 109:619-632. https://doi.org/10. 1016/j.rser.2019.03.055

Min B, Wang MC, Fu XR, Zhao C (2016) Offshore wind power as the development trend of wind industry: developments of global offshore wind power. International Petroleum Economics 24:29-36. https://doi.org/10.3969/j.issn.1004-7298.2016.04.006

Murthy KSR, Rahi OP (2017) A comprehensive review of wind resource assessment. Renew Sust Energ Rev 72:1320-1342. https://doi.org/ 10.1016/j.rser.2016.10.038

Nazir MS, Alturise F, Alshmrany S, Nazir HMJ, Bilal M, Abdalla AN, Sanjeevikumar P, M. Ali Z (2020a) Wind generation forecasting methods and proliferation of artificial neural network: a review of five years research trend. Sustainability. 12:3778. https://doi.org/10. 3390/su12093778

Nazir MS, Ali Z, Bilal M, Sohail H, Iqbal H (2020b) Environmental impacts and risk factors of renewable energy paradigm - a review. Environ Sci Pollut Res 27:33516-33526. https://doi.org/10.1007/ s11356-020-09751-8

Nazir MS, Bilal M, Sohail HM, Liu B, Chen W, Iqbal H (2020c) Impacts of renewable energy atlas: reaping the benefits of renewables and biodiversity threats. Int J Hydrog Energy 45:22113-22124. https:// doi.org/10.1016/j.ijhydene.2020.05.195

NDRC (2016) Notice of the national development and reform commission on adjusting the benchmarking on-grid tariff of photovoltaic onshore wind power. Available at: http:/www.gov.cn/ xinwen/2016-12/28/content 5153820.htm . Accessed 20 June 2020

NDRC (2019a) Industrial structure adjustment guidance catalog (2019 Edition, Draft for Comment). Available at: https:/www.sohu.com/ a/307121294_745358. Accessed 20 June 2020

NDRC (2019b) Notice on improving the on-grid tariff policy for wind power. Available at: http://www.gov.cn/xinwen/2019-05/25/ content 5394615.htm . Accessed 20 June 2020 
NDRC, NEA (2019) Notice on actively promoting the work related to unsubsidized parity of wind power and photovoltaic power generation. Available at: http://news.bjx.com.cn/html/20190109/955434. shtml . Accessed 20 June 2020

NEA (2014) Notice on the National Offshore Wind Power Development and construction plan (2014-2016). Official website of NEA.. http:// zfxxgk.nea.gov.cn/auto87/201412/t20141212_1869.htm. Accessed 20 June 2020

NEA (2016) Thirteenth Five-Year Plan for wind power development. Polaris Wind Power Web. http://news.bjx.com.cn/html/20161129/ 792710.shtml . Accessed 20 June 2020

NEA (2018) Notice on relevant requirements for wind power construction management in 2018. Available at: http://zfxxgk.nea.gov.cn/ auto87/201805/t20180524 3184.htm . Accessed 20 June 2020

NEA (2021) Transcript of online press conference of national energy administration in the first quarter of 2021. Official website of NEA http://wwwneagovcn/2021-01/30/c 139708580htm Accessed 26 March 2021

NEA, State Oceanic Administration (2016) Administrative measures for offshore wind power development and construction. Official website of NEA.. http://zfxxgk.nea.gov.cn/auto87/201701/ t20170104 2417.htm. Accessed 20 June 2020

New China Net (2020) Carry on the past and open up a new journey of global response to climate change (speech at the climate ambition summit). New China Net http://wwwxinhuanetcom/2020-12/12/c 1126853600htm Accessed 26 March 2021

Nezhad MM, Shaik RU, Heydari A, Razmjoo A, Arslan N, Garcia DA (2020) A SWOT analysis for offshore wind energy assessment using remote-sensing potential. Appl Sci 10:6398. https://doi.org/10. 3390/app 10186398

Nguyen TAT, Chou SY (2019) Improved maintenance optimization of offshore wind systems considering effects of government subsidies, lost production and discounted cost model. Energy 187:115909. https://doi.org/10.1016/j.energy.2019.115909

O'Kelly BC (2019) Global status of wind power generation: theory, practice, and challenges. Int. J Green Energy 16:1073-1090. https://doi. org/10.1080/15435075.2019.1597369

Papiez M, Smiech S, Frodyma K (2019) Factors affecting the efficiency of wind power in the European Union countries. Energy Policy 132: 965-977. https://doi.org/10.1016/j.enpol.2019.06.036

Peng T, Zhang C, Zhou J, Nazir MS (2020) Negative correlation learning-based RELM ensemble model integrated with OVMD for multi-step ahead wind speed forecasting. Renew Energy 156:804 819. https://doi.org/10.1016/j.renene.2020.03.168

Polaris wind power network (2018) Five factors that must be considered in site selection of offshore wind power. http://news.bjx.com.cn/ html/20180521/899083.shtml. Accessed 25 October 2020

Ranthodsang M, Waewsak J, Kongruang C, Gagnon Y (2020) Offshore wind power assessment on the western coast of Thailand. Energy Rep 6:1135-1146. https://doi.org/10.1016/j. egyr.2020.04.036

Reichardt K, Rogge K (2015) How the policy mix impacts innovation: findings from company case studies on offshore wind in Germany. Environmental Innovation and Societal Transitions 18:62-81 https://doi.org/10.1016/j.eist.2015.08.001

Shao M, Han Z, Sun J, Xiao C, Zhang S, Zhao Y (2020) A review of multi-criteria decision making applications for renewable energy site selection. Renew Energy 157:377-403. https://doi.org/10. 1016/j.renene.2020.04.137

Shen Z, Hu XQ, Qiu J (2021) Research on the key influence factors of sports and medicine integration under healthy China strategy: analysis based on interpretative structure model. Journal of Capital University of Physical Education and Sports 33:31-39. https://doi. org/10.14036/j.cnki.cn11-4513.2021.01.004
Sherman P, Chen XY, McElroy M (2020) Offshore wind: an opportunity for cost-competitive decarbonization of China's energy economy. Sci Adv 6:eaax9571. https://doi.org/10.1126/sciadv.aax9571

Sun YL (2020) Current situation and Prospect of global offshore wind power market. Wind Energy 2020(09):40-43

Tahir ZUR, Kanwal A, Afzal S, Ali S, Hayat N, Abdullah M, Saeed UB (2020) Wind energy potential and economic assessment of southeast of Pakistan. Int J Green Energy 18:1-16. https://doi.org/10.1080/ 15435075.2020.1814298

Tercan E, Tapkn S, Latinopoulos D, Dereli MA, Ak MF (2020) A GISbased multi-criteria model for offshore wind energy power plants site selection in both sides of the Aegean Sea. Environ Monit Assess 192:652. https://doi.org/10.1007/s10661-020-08603-9

$\mathrm{Tu}$ CY (2019) Economic analysis and development policy research of wind power projects. Dissertation, North China Electric Power University (Beijing)

Wang JM, Kang JJ (2017) Analysis on influencing factors of energy demand based on interpretative structural modeling. Electric Power 50:31-36. https://doi.org/10.11930/j.issn.1004-9649. 201607096

Wang B, Shi SJ, Yang L (2017) Analysis on the causes of university canteen congestion based on ISM. China CIO News. 104-107. https://doi.org/10.3969/j.issn.1001-2362.2017.10.072

Wang JZ, Song XJ, Du HT (2020) Research on the influencing factors of implementing industrial internet in China based on interpretative structural model. Chin Soft Sci 06:30-41

Warfield JN (1978) Societal systems planning, policy and complexity. Proc IEEE 66:362-363. https://doi.org/10.1109/PROC. 1978.10919

Wu YN, Tao Y, Zhang BY, Wang SM, Zhou JL (2019) A decision framework of offshore wind power station site selection using a PROMETHEE method under intuitionistic fuzzy environment: a case in China[J]. Ocean Coastal Manage 184:105016. https://doi. org/10.1016/j.ocecoaman.2019.105016

Xu XX, Zou PXW (2020) Analysis of factors and their hierarchical relationships influencing building energy performance using interpretive structural modelling (ISM) approach. J Clean Prod 2020: 122650. https://doi.org/10.1016/j.jclepro.2020.122650

Xu MJ, Hu ZG, Shan BG, Wu JY (2009) Analysis on influencing factors of electricity demand by using interpretative structural modeling. Electric Power. 42:1-5. https://doi.org/10.3969/j.issn.1004-9649. 2009.04.001

Xu LP, Wu Q, Cui LR (2019) Strong offshore wind power to meet the new pattern of bidding and internet access. China Energy News 1014(010)

Xu Y, Yang K, Yuan JH (2021) Levelized cost of offshore wind power in China. Environ Sci Pollut Res. https://doi.org/10.1007/s11356-02112382-2

Xue WX, Liu J (2008) An analysis of relative structure on main influence factors of digital divide. System Engineering Theory and Practice: 85-91. https://doi.org/10.3321/j.issn:1000-6788.2008.05.011

Yang JB, Liu QY, Li X, Cui XD (2017) Overview of wind power in China: status and future. Sustainability 9:1454. https://doi.org/10. $3390 /$ su9081454

Zhang K (2019) The study on China's industrial policy of offshore wind power. Dissertation, Wuhan University

Zhang JL, Huang JT (2018) Analysis on cost and revenue sensitivity of offshore wind power. Water Power 44:105-108. https://doi.org/10. 3969/j.issn.0559-9342.2018.12.026

Zhang XY, Wang WH, Yan HL, Qi Y (2015) Research on influencing factors and governance path of offshore wind farm revenue. Management observer 04:71-72 http://dx.doi.org/CNKI:SUN: GLKW.0.2015-04-029

Zhang HM, Zheng Y, Zhou DQ, Long XL (2018) Selection of key technology policies for Chinese offshore wind power: a perspective on 
patent maps. Mar Pol 93:47-53. https://doi.org/10.1016/j.marpol. 2018.03.030

Zhang SJ, Wei J, Chen X, Zhao YH (2020) China in global wind power development: role, status and impact. Renew Sust Energ Rev 127: 109881. https://doi.org/10.1016/j.rser.2020.109881

Zhao J, Guo ZH, Guo YL, Zhang Y, Lin WT, Hu JM (2019) Wind resource assessment based on numerical simulations and an optimized ensemble system. Energy Conv Manag 201:112164. https:// doi.org/10.1016/j.enconman.2019.112164
Zheng Y (2017) Key technology selection of offshore wind power in the patent map perspective. Dissertation, Nanjing University of Information Science \& Technology

Publisher's note Springer Nature remains neutral with regard to jurisdictional claims in published maps and institutional affiliations. 